p-ISSN: 1410-0029; e-ISSN2549-6786

Agrin Vol. 23, No. 1, April 2019

\title{
EFISIENSI PEMANFAATAN LAHAN DAN ANALISIS FINANSIAL USAHA TANI BAWANG MERAH BERPENYAKIT MOLER PADA BERBAGAI POLA TANAM DAN DOSIS PUPUK KALIUM
}

\section{The Efficiency of Land Use and The Financial Analysis of Moler Diseased Red Onion Farm Business on Various Planting Patterns and Dosage of Potassium Fertilizer}

\author{
Noor Laili Aziza* \\ Jurusan Agroekoteknologi, Universitas Lambung Mangkurat, Banjarbaru \\ *Alamat Korespondensi: noor_lailiaziza@yahoo.co.id
}

\begin{abstract}
ABSTRAK
Bawang merah merupakan komoditas sayuran dengan nilai ekonomi tinggi, namun produktivitasnya di Kalimantan Selatan masih tergolong rendah. Salah satu penyebabnya adalah patogen Fusarium spp.. Patogen Fusarium spp. diduga dapat ditekan melalui manipulasi lingkungan seperti pengubahan pola tanam bawang merah dari monokultur menjadi tumpang sari sekaligus pengaplikasian beberapa dosis pupuk kalium dalam usaha peningkatan ketahanan tanaman. Tujuan dari penelitian ini adalah untuk mengetahui efisiensi pemanfaatan lahan dan analisis finansial usaha tani bawang merah berpenyakit moler pada lingkungan yang telah dimanipulasi. Penelitian dilaksanakan di Laboratorium Fitopatologi Fakultas Pertanian Universitas Lambung Mangkurat Banjarbaru dan lahan Balai Penelitian Pertanian Lahan Rawa (BALITTRA) Banjarbaru dari bulan Oktober 2015Maret 2016. Penelitian ini menggunakan metode deskriptif dari tiga faktor dan dua kali ulangan. Faktor pertama yaitu Fusarium spp.: tanpa Fusarium spp. dan dengan Fusarium spp.. Faktor kedua berupa dosis pupuk Kalium: $60 \mathrm{~kg} \mathrm{ha}^{-1}, 120 \mathrm{~kg} \mathrm{ha}^{-1}$, dan $180 \mathrm{~kg} \mathrm{ha}^{-1}$. Faktor ketiga berupa pola tanam: monokultur bawang merah, monokultur bawang sabrang, tanaman bawang merah 1 baris dan bawang sabrang 1 baris, tanaman bawang merah 2 baris dan bawang sabrang 1 baris, dan tanaman bawang sabrang mengelilingi pertanaman bawang merah. Total terdapat 60 petak percobaan dengan variabel pengamatan berupa laba, Land Equivalent Ratio (LER), dan analisis benefit cost ratio $(\mathrm{B} / \mathrm{C})$. Hasil penelitian menunjukkan efisiensi pemanfaatan lahan dan analisis finansial usaha tani terbaik terdapat pada perlakuan $120 \mathrm{~kg} \mathrm{ha}^{-1} \mathrm{~K}_{2} \mathrm{O}$ dengan pola tanam tanaman bawang sabrang mengelilingi pertanaman bawang merah berpenyakit moler.
\end{abstract}

Kata Kunci: Fusarium spp., pola tanam, B/C, LER

\begin{abstract}
Red onion is one of the vegetable crops with high economic value, but its productivity in South Kalimantan is still relatively low which is caused by pathogen Fusarium spp. Fusarium spp. can be reduced by using environment manipulation such as changing the planting patterns of red onion from monoculture to intercropping and applying the various dosage of Potassium fertilizer to increasing the plant resistence. The purpose of this research was conducted to determine the efficiency of land use and the financial analysis of moler diseased red onion farm business on manipulated environment. This research was conducted at Laboratory Phytopathology Agriculture Faculty of Lambung Mangkurat University and a land of Swamp Land Agricultural Research Center Banjarbaru from October 2015 to March 2016. This research applied descriptive method of three factors and two repetitions. The first factor was Fusarium spp.: without Fusarium spp. and with Fusarium spp.. The second factor was the dosage of Potassium fertilizer: $60 \mathrm{~kg} \mathrm{ha}^{-1}, 120 \mathrm{~kg} \mathrm{ha}^{-1}$, and $180 \mathrm{~kg} \mathrm{ha-1}$. The third factor were the forms of planting pattern: red onion monoculture, sabrang onion monoculture, 1 line of red onion and 1 line of sabrang onion, 2 lines of red onion and 1 line of sabrang onion, and sabrang onion surrounding the crop of red onion. There were 60 plot unit used with observation variabels were profit, Land Equivalent Ratio (LER), and benefit cost ratio $(B / C)$ analysis. The results showed that the best efficiency of land use and the financial analysis of farm business found on treatment of $120 \mathrm{~kg} \mathrm{ha}^{-1} \mathrm{~K}_{2} \mathrm{O}$ in planting pattern of the sabrang onion planting pattern surrounding the crop of moler diseased red onion.
\end{abstract}

Keyword: Fusarium spp, planting patterns, B/C, LER 


\section{PENDAHULUAN}

Pengembangan bawang merah di Kalimantan Selatan saat ini galak dilakukan karena kebutuhan konsumen yang semakin meningkat dan komoditas ini memiliki nilai ekonomi yang tinggi. Produktivitas bawang merah di Kalimantan Selatan masih tergolong rendah dibandingkan dengan produktivitas bawang merah secara nasional. Salah satu penyebabnya yaitu dari faktor biotik berupa penyakit busuk pangkal umbi (moler). Penyakit yang menyerang bagian pangkal umbi tanaman bawang merah ini disebabkan oleh Fusarium spp. (Nugroho et al., 2011).

Penyakit moler merupakan penyakit yang umum ditemukan di pertanaman bawang merah dengan intensitas penyakit yang bervariasi dan bervariasinya intensitas penyakit tersebut disebabkan karena varietas bawang merah yang ditanam (Nugroho et al., 2011), virulensi patogen, dan kondisi lingkungan. Pengendalian penyakit ini umumnya menggunakan pestisida kimiawi yang diketahui dapat menimbulkan dampak negatif bagi lingkungan, organisme bukan sasaran, kesehatan masyarakat, dan dari segi ekonomi. Sehingga untuk mengendalikan penyakit moler tersebut, perlu dilakukan pengendalian penyakit terpadu yang mengutamakan keramahan lingkungan dan secara ekonomi dapat juga menguntungkan.

Pengendalian penyakit secara terpadu salah satunya dengan cara memanipulasi kondisi lingkungan. Hal ini dikarenakan kecilnya ukuran patogen menyebabkannya lebih peka terhadap lingkungan. Penelitian ini dilakukan dengan pengubahan pola tanam bawang merah dari monokultur menjadi tumpang sari yang diharapkan mampu mempengaruhi siklus hidup patogen tersebut. Tumpang sari dilakukan dengan tanaman bawang sabrang yang merupakan tanaman anti patogen tular tanah. Selain itu, pada pertanaman bawang merah juga akan diaplikasikan pupuk kalium yang berfungsi untuk meningkatkan ketahanan tanaman terhadap penyakit (Sumarni et al., 2012), khususnya terhadap penyakit moler sekaligus meningkatkan produksi tanaman bawang merah ini sendiri.

Pengambilan keputusan pengaplikasian manipulasi lingkungan ini dapat dilihat dari efisiensi pemanfaatan lahan dan analisis finansial usaha tani sehingga dapat menjadi acuan dasar bagi para petani dalam membudidayakan bawang merah berpenyakit moler di Kalimantan Selatan. Berdasarkan hal tersebut, perlu dilakukan evaluasi perlakuan pemanipulasian lingkungan tersebut untuk mengetahui keefisienan pemanfaatan lahan berupa perhitungan Land Equivalent Ratio (LER) karena penelitian ini berhubungan dengan pola tanam dan menganalisis finansial usaha tani dengan memperhitungkan laba dan benefit cost ratio $(\mathrm{B} / \mathrm{C})$. Oleh karena itulah dilakukan penelitian ini dengan tujuan untuk mengetahui efisiensi pemanfaatan lahan dan analisis finansial usaha tani bawang merah 
berpenyakit moler pada lingkungan yang telah dimanipulasi.

\section{METODE PENELITIAN}

Bahan dan alat yang digunakan pada penelitian ini adalah benih umbi bawang merah varietas Bima Brebes, benih umbi bawang sabrang, lahan pertanaman bawang merah, pupuk $\mathrm{N}$, pupuk $\mathrm{P}$, pupuk kalium berupa $\mathrm{K}_{2} \mathrm{O}$, kapur dolomit, pupuk kandang, peralatan laboratorium, cangkul, alat pengukur panjang, papan nama petak percobaan, handsprayer, dan peralatan dokumentasi.

Penelitian

dilaksanakan

di

Laboratorium Fitopatologi Fakultas Pertanian Universitas Lambung Mangkurat Banjarbaru dan lahan Balai Penelitian Pertanian Lahan Rawa (BALITTRA) Banjarbaru dari bulan Oktober 2015 - Maret 2016. Lahan yang akan ditanami bawang merah dipersiapkan terlebih dahulu dengan cara membersihkannya dari gulma dan dibuat petak percobaan dengan ukuran 1,60 m x 1,20 m dengan ketinggian petakan yaitu $40 \mathrm{~cm}$ serta jarak antar petak percobaan adalah $30 \mathrm{~cm}$. Tahap berikutnya yaitu pengaplikasian kapur dolomit 4 t.ha $^{-1}$ dan pupuk kandang sebanyak 15 t.ha $^{-1}$ (Latarang dan Syakur, 2006).

Benih umbi bawang merah dan bawang sabrang yang digunakan memiliki kisaran berat antara 5-8 $\mathrm{g}$ dan ditanam dengan jarak tanam $20 \mathrm{~cm}$ x $20 \mathrm{~cm}$ dan disesuaikan dengan pola tanam yang menjadi perlakuan.
Penanaman dilakukan pada sore hari dan benih bawang yang ditanam merupakan benih yang telah dipotong $1 / 3$ bagiannya. Pemupukan unsur N sebanyak 90 kg.ha ${ }^{-1}$ dan P 80 kg.ha ${ }^{-1}$ dilakukan secara bertahap, yaitu saat tanaman bawang merah berumur $10 \mathrm{hst}$ dan 37 hst dan saat tanaman bawang sabrang berumur 10 hst dan 67 hst dan $\mathrm{K}_{2} \mathrm{O}$ sesuai dengan perlakuan ketika tanaman bawang merah dan bawang sabrang masing-masing berumur 37 hst dan 67 hst.

Pendekatan penelitian ini yaitu dengan melakukan pengamatan langsung pada objek penelitian dengan menganalisis efisiensi pemanfaatan lahan dan analisis finansial usaha tani bawang merah berpenyakit moler (pendekatan agribisnis) di 60 petakan penelitian yang meliputi 30 petak kombinasi ketiga faktor dengan dua ulangan. Faktor yang dimaksud yaitu:

1. Pengaplikasian patogen Fusarium spp. di lahan pertanaman, yang terdiri dari:

$$
\begin{aligned}
& \mathrm{f}_{1}=\text { tanpa Fusarium spp. } \\
& \mathrm{f}_{2}=\text { dengan Fusarium spp. }
\end{aligned}
$$

2. Pengaplikasian tiga dosis pupuk $\mathrm{K}_{2} \mathrm{O}$, yang terdiri dari:

$$
\begin{aligned}
& \mathrm{k}_{1}=60 \mathrm{~kg} \mathrm{ha}^{-1} \mathrm{~K}_{2} \mathrm{O} \\
& \mathrm{k}_{2}=120 \mathrm{~kg} \mathrm{ha}^{-1} \mathrm{~K}_{2} \mathrm{O} \\
& \mathrm{k}_{3}=180 \mathrm{~kg} \mathrm{ha}^{-1} \mathrm{~K}_{2} \mathrm{O}
\end{aligned}
$$

3. Pengaplikasian lima pola tanam tanaman bawang merah dan bawang sabrang, yang terdiri dari:

$\mathrm{j}_{1}=$ monokultur bawang merah $\mathrm{j}_{2}=$ monokultur bawang sabrang 
$\mathrm{j}_{3}=$ tanaman bawang merah 1 baris dan bawang sabrang 1 baris (1:1)

$\mathrm{j}_{4}=$ tanaman bawang merah 2 baris dan bawang sabrang 1 baris (2:1)

$\mathrm{j}_{5}=$ tanaman bawang sabrang ditanam mengelilingi pertanaman bawang merah

Petak percobaan dengan pola tanam monokultur bawang merah dan bawang sabrang masing-masing terdiri dari 35 bawang merah dan 35 bawang sabrang, petak percobaan dengan pola tanam bawang merah dan bawang sabrang 1:1 terdiri dari 15 bawang merah dan 20 bawang sabrang, petak percobaan dengan pola tanam bawang merah dan bawang sabrang 2:1 terdiri dari 20 bawang merah dan 15 bawang sabrang, dan petak percobaan dengan pola tanam bawang sabrang mengelilingi pertanaman bawang merah terdiri dari 15 bawang merah dan 20 bawang sabrang. Sehingga secara keseluruhan diperlukan 1020 benih umbi bawang merah dan 1080 benih umbi bawang sabrang.

Parameter pengamatan yang diamati pada penelitian ini yaitu laba, LER, dan B/C.

1. Laba didapatkan dari perhitungan selisih antara total biaya produksi dengan penerimaan dari pengaplikasian lima pola tanam bawang merah dan bawang sabrang.

2. LER dihitung berdasarkan produktivitas bawang merah dan bawang sabrang pada pola tanam monokultur maupun tumpangsari yang diaplikasikan bersama
Fusarium spp. dan pupuk $\mathrm{K}_{2} \mathrm{O}$, dengan rumus (Karima, Nawawi, \& Herlina, 2013):

$$
\mathrm{LER}=\sum \frac{Y i}{Y i i}
$$

Keterangan:

$\mathrm{Yi}=$ produktivitas tanaman dengan pola tanam tumpangsari $+(+/-)$ Fusarium spp. $+\mathrm{K}_{2} \mathrm{O}$

Yii $=$ produktivitas tanaman dengan pola tanam monokultur $+(+/-)$ Fusarium spp. $+\mathrm{K}_{2} \mathrm{O}$

3. Analisis $\mathrm{B} / \mathrm{C}$ dilakukan untuk mengetahui kelayakan ekonomi suatu usaha tani pada berbagai pola tanam bawang merah. B/C dihitung dengan rumus (Rifai dkk., 2014), Sistem usahatani layak untuk dikembangkan jika $\mathrm{B} / \mathrm{C}$ ratio $>1$ :

$$
\mathrm{B} / \mathrm{C} \text { ratio }=\frac{\mathrm{B}}{\mathrm{C}}
$$

Keterangan:

$$
\begin{aligned}
& \mathrm{B}=\text { Keuntungan (Rupiah) } \\
& \mathrm{C}=\text { pengeluaran (Rupiah) }
\end{aligned}
$$

\section{HASIL DAN PEMBAHASAN}

\section{Laba Usaha Tani Bawang Merah pada Berbagai Pola Tanam}

Selisih antara harga penjualan dengan harga pembelian atau biaya produksi dinamakan laba atau keuntungan. Harga penjualan merupakan penerimaan bersih dari hasil penjualan produk, sedangkan biaya produksi adalah biaya yang dikeluarkan secara tetap (Timisela, 2008). Pada penelitian ini, biaya produksi yang harus dikeluarkan meliputi biaya benih umbi, pupuk, kapur, dan 
p-ISSN: 1410-0029; e-ISSN2549-6786

Agrin Vol. 23, No. 1, April 2019

tenaga kerja, sehingga dalam satu kali musim

tanam bawang merah, laba yang diperoleh

disajikan pada Tabel 1.

Tabel 1. Aplikasi pola tanam terhadap rata-rata laba yang dihasilkan satu kali musim tanam

\begin{tabular}{lr}
\hline \multicolumn{1}{c}{ Perlakuan } & Laba (Rp) \\
\hline j1 (monokultur bawang merah) & 37.638 .397 \\
j2 (monokultur bawang sabrang) & 313.984 .464 \\
j3 (tanaman bawang merah 1 baris dan bawang sabrang 1 baris) & 242.732 .604 \\
j4 (tanaman bawang merah 2 baris dan bawang sabrang 1 baris) & 193.039 .079 \\
j5 (tanaman bawang sabrang ditanam mengelilingi pertanaman & 239.300 .569 \\
$\quad$ bawang merah) & \\
\hline
\end{tabular}

Keterangan: Data primer diolah (2016).

Tabel 1. menunjukkan bahwa dari segi pola tanam monokultur, laba yang diperoleh dari pola tanam j2 (monokultur bawang sabrang) lebih besar dibandingkan laba yang diperoleh dari pola tanam $\mathrm{j}_{1}$ (monokultur bawang merah). Sedangkan dari segi pola tanam tumpangsari, laba yang diperoleh dari pola tanam tanam $\mathrm{j}_{3}$ (tanaman bawang merah 1 baris dan bawang sabrang 1 baris) lebih besar dibandingkan dengan pola $\mathrm{j}_{4}$ (tanaman bawang merah 2 baris dan bawang sabrang 1 baris) dan $\mathrm{j}_{5}$ (tanaman bawang sabrang ditanam mengelilingi pertanaman bawang merah).

Secara keseluruhan, pola tanam monokultur bawang sabrang lebih memberikan laba yang paling besar dibandingkan perlakuan pola tanam lainnya dan pola tanam bawang merah memberikan laba yang paling kecil dibandingkan perlakuan pola tanam lainnya. Banyaknya laba yang diperoleh pada monokultur bawang sabrang berasal dari harga jualnya yang tinggi dibandingkan dengan tanaman bawang merah. Berdasarkan hasil survey penjualan di Pasar Banjarbaru Kalimantan Selatan, harga bawang merah berkisar sebesar Rp. 25.000/kg, sedangkan harga bawang sabrang adalah sebesar Rp. $60.000 / \mathrm{kg}$.

Pengambilan keputusan pola tanam yang diambil juga perlu pertimbangan permintaan pasar, salah satunya dari segi selera masyarakat. Umum terjadi bahwa bawang merah selalu dibutuhkan masyarakat sehari-hari dan salah satunya sebagai bumbu dapur, sedangkan bawang sabrang akan dibutuhkan masyarakat ketika memerlukan pengobatan saja. Sehingga, keputusan penggunaan pola tanam yang akan diambil sebaiknya disesuaikan dengan sasaran pemasaran dan permintaan pasar.

Keseimbangan sasaran pemasaran, permintaan pasar, dan laba dapat tercapai ketika dilakukan penanaman tumpangsari antara bawang merah dan bawang sabrang. Pada penelitian ini, pola tanam tanaman bawang merah 1 baris dan tanaman bawang sabrang 1 baris menjadi pola tanam tumpang 
sari terbaik yang dapat diaplikasikan. Hal ini terkait dengan kompetisi antara bawang merah dan bawang sabrang berupa kompetisi kompensasi sekaligus eksudat akar tanaman bawang sabrang yang lebih mampu secara optimal dalam menekan perkembangan serta penyebaran penyakit moler.

Bentuk kompetisi tanaman tumpangsari pada umumnya terbagi menjadi tiga tipe. Pertama adalah kompetisi yang mengakibatkan hasil dari masing-masing jenis tanaman dalam tumpangsari lebih rendah dari hasil yang diharapkan. Ini berarti bahwa tanaman mengalami proses saling menghambat. Kedua adalah kompetisi yang mengakibatkan hasil yang dari masingmasing jenis tanaman lebih besar dari hasil yang diharapkan. Dalam keadaan yang demikian, tanaman mengalami proses saling mengisi atau saling kerja sama. Ketiga adalah kompetisi yang mengakibatkan hasil dari suatu jenis tanaman lebih tinggi dari hasil yang diharapkan dan hasil dari suatu jenis tanaman lainnya lebih rendah dari hasil yang diharapkan. Peristiwa terakhir ini adalah akibat kemampuan kompetisi yang berbeda di antara kedua jenis tanaman yang dikenal dengan peristiwa kompensasi (Andersen, 2005).

Land Equivalent Ratio (LER) pada Bawang Merah Berpenyakit Moler pada Berbagai Pola Tanam dan Dosis Pupuk Kalium

Hasil perhitungan nilai nisbah kesetaraan lahan atau LER menunjukkan bahwa terdapat beberapa perlakuan yang memiliki nilai LER di bawah 1,00. Hal ini menandakan bahwa pemanfaatan lahan pada aplikasi perlakuan tersebut masih belum efektif (Tabel 2). Sedangkan pola tanam yang memiliki nilai LER di atas 1,00 berarti sistem pertanaman tersebut mampu meningkatkan produktivitas lahan sehingga lebih efisien dibandingkan dengan pola tanam monokultur (Karima et al., 2013) dan terdapat hubungan positif di antara jenis tanaman yang ditanam secara tumpang sari tersebut (Handayani, 2011).

Tabel 2. menunjukkan bahwa perlakuan kombinasi $\mathrm{f}_{2} \mathrm{k}_{2} \mathrm{j}_{5}$ (dengan Fusarium spp. + $120 \mathrm{~kg} \mathrm{ha}{ }^{-1} \mathrm{~K}_{2} \mathrm{O}+$ pola tanam tanaman bawang sabrang mengelilingi pertanaman bawang merah) memiliki nilai LER tertinggi, yaitu sebesar 1,63. Hal ini berarti pemanfaatan lahan yang telah terinfeksi patogen moler yang diaplikasikan dengan kombinasi perlakuan $120 \mathrm{~kg} \mathrm{ha}^{-1} \mathrm{~K}_{2} \mathrm{O}$ dengan pola tanam tanaman bawang sabrang mengelilingi pertanaman bawang merah lebih efisien sebesar $63 \%$ dibandingkan dengan pola tanam monokulturnya pada dosis pupuk $\mathrm{K}_{2} \mathrm{O}$ yang sama di lahan yang telah terinfeksi patogen moler.

Keuntungan yang diperoleh dengan penanaman secara tumpangsari di antaranya yaitu memudahkan pemeliharaan, memperkecil resiko gagal panen, hemat dalam pemakaian sarana produksi, dan 
p-ISSN: 1410-0029; e-ISSN2549-6786

Agrin Vol. 23, No. 1, April 2019

mampu meningkatkan efisiensi penggunaan

lahan (Permanasari dan Kastono, 2012).

Tabel 2. LER pada pertanaman bawang merah dan bawang sabrang

\begin{tabular}{ccccccc}
\hline & & $\mathrm{f}_{1}$ & & & $\mathrm{f}_{2}$ & \\
\hline & $\mathrm{j}_{3}$ & $\mathrm{j}_{4}$ & $\mathrm{j}_{5}$ & $\mathrm{j}_{3}$ & $\mathrm{j}_{4}$ & $\mathrm{j}_{5}$ \\
\hline $\mathrm{k}_{1}$ & 1,29 & 1,11 & 1,29 & 1,41 & 1,09 & 1,06 \\
$\mathrm{k}_{2}$ & 0,68 & 0,72 & 0,95 & 1,08 & 1,46 & 1,63 \\
$\mathrm{k}_{3}$ & 1,01 & 0,80 & 0,77 & 1,13 & 1,19 & 0,96 \\
\hline
\end{tabular}

Keterangan: $\mathrm{f}_{1}=$ tanpa Fusarium spp., $\mathrm{f}_{2}=$ dengan Fusarium spp., $\mathrm{k}_{1}=60 \mathrm{~kg} \mathrm{ha}^{-1} \mathrm{~K}_{2} \mathrm{O}$, $\mathrm{k}_{2}=120 \mathrm{~kg} \mathrm{ha}^{-1} \mathrm{~K}_{2} \mathrm{O}, \mathrm{k}_{3}=180 \mathrm{~kg} \mathrm{ha}^{-1} \mathrm{~K}_{2} \mathrm{O}, \mathrm{j}_{3}=1: 1, \mathrm{j}_{4}=2: 1, \mathrm{j}_{5}=$ tanaman bawang sabrang ditanam mengelilingi pertanaman bawang merah.

Keuntungan yang diperoleh dengan penanaman secara tumpangsari di antaranya yaitu memudahkan pemeliharaan, memperkecil resiko gagal panen, hemat dalam pemakaian sarana produksi, dan mampu meningkatkan efisiensi penggunaan lahan (Permanasari dan Kastono, 2012). Keuntungan lainnya yaitu akan terjadi peningkatan efisiensi tenaga kerja dan penyerapan sinar matahari, serta akan tercipta stabilitas biologis yang dapat menekan serangan hama dan penyakit (Handayani, 2011).

Benefit Cost Ratio (B/C) pada Bawang Merah Berpenyakit Moler pada Berbagai Pola Tanam dan Dosis Pupuk Kalium

$\mathrm{B} / \mathrm{C}$ dilakukan dengan cara menghitung pemasukan, pengeluaran, dan laba yang diperoleh, sehingga diketahui bahwa beberapa kombinasi perlakuan yang diaplikasikan memiliki B/C kurang dari 1,00 (Tabel 3).

Tabel 3. menunjukkan bahwa seluruh perlakuan memiliki nilai B/C lebih dari 1,00, kecuali perlakuan kombinasi $\mathrm{f}_{2} \mathrm{k}_{1} \mathrm{j}_{1}$ (dengan
Fusarium spp. $+60 \mathrm{~kg} \mathrm{ha}^{-1} \mathrm{~K}_{2} \mathrm{O}+$ pola tanam monokultur bawang merah), yaitu 0,51 dan perlakuan kombinasi $\mathrm{f}_{2} \mathrm{k}_{2} \mathrm{j}_{1}$ (dengan Fusarium spp. $+120 \mathrm{~kg} \mathrm{ha}^{-1} \mathrm{~K}_{2} \mathrm{O}+$ pola tanam monokultur bawang merah), yaitu 0,86 . Selain itu, perlakuan kombinasi $\mathrm{f}_{2} \mathrm{k}_{2} \mathrm{j}_{5}$ (dengan Fusarium spp. $+120 \mathrm{~kg} \mathrm{ha}^{-1} \mathrm{~K}_{2} \mathrm{O}+$ pola tanam tanaman bawang sabrang mengelilingi pertanaman bawang merah) memiliki nilai $\mathrm{B} / \mathrm{C}$ tertinggi, yaitu sebesar 3,42 . Hal ini berarti pemanfaatan lahan pada lahan terinfeksi patogen moler yang diaplikasikan dengan kombinasi perlakuan $120 \mathrm{~kg} \mathrm{ha}^{-1} \mathrm{~K}_{2} \mathrm{O}$ dengan pola tanam tanaman bawang sabrang mengelilingi pertanaman bawang merah paling layak untuk dikembangkan karena memberikan keuntungan yang lebih besar, yaitu akan menghasilkan penerimaan Rp 342 pada akhir produksi setiap menginvestasikan atau mengeluarkan Rp 100 untuk pola tanam ini. Sistem usaha tani ini layak dikembangkan apabila $\mathrm{B} / \mathrm{C} \geq 1$ karena usaha tani tersebut menguntungkan secara ekonomi (Rifai dkk., 2014). 
Tabel 3. B/C pada pertanaman bawang merah dan bawang sabrang

\begin{tabular}{|c|c|c|c|c|c|c|c|c|c|c|}
\hline & & & $\mathrm{f}_{1}$ & & & & & $f_{2}$ & & \\
\hline & $\mathrm{j}_{1}$ & $\mathrm{j}_{2}$ & $\mathrm{j}_{3}$ & $\mathrm{j}_{4}$ & $\mathrm{j}_{5}$ & $\mathrm{j}_{1}$ & $\mathrm{j}_{2}$ & $\mathrm{j}_{3}$ & $\mathrm{j}_{4}$ & $\mathrm{j}_{5}$ \\
\hline $\mathrm{k}_{1}$ & 1,83 & 2,03 & 2,79 & 2,39 & 2,67 & 0,51 & 3,09 & 2,84 & 2,13 & 2,50 \\
\hline $\mathrm{k}_{2}$ & 1,18 & 3,06 & 2,15 & 2,14 & 2,65 & 0,86 & 3,15 & 2,97 & 2,45 & 3,42 \\
\hline $\mathrm{k}_{3}$ & 1,70 & 3,33 & 2,77 & 2,33 & 2,39 & 1,41 & 2,24 & 2,22 & 2,35 & 2,04 \\
\hline
\end{tabular}

Keterangan: $\mathrm{f}_{1}=$ tanpa Fusarium spp., $\mathrm{f}_{2}=$ dengan Fusarium spp., $\mathrm{k}_{1}=60 \mathrm{~kg} \mathrm{ha}^{-1} \mathrm{~K}_{2} \mathrm{O}$, $\mathrm{k}_{2}=120 \mathrm{~kg} \mathrm{ha}^{-1} \mathrm{~K}_{2} \mathrm{O}, \mathrm{k}_{3}=180 \mathrm{~kg} \mathrm{ha}^{-1} \mathrm{~K}_{2} \mathrm{O}, \mathrm{j}_{1}=$ monokultur bawang merah, $\mathrm{j}_{2}$ $=$ monokultur bawang sabrang, $\mathrm{j}_{3}=1: 1, \mathrm{j}_{4}=2: 1, \mathrm{j}_{5}=$ tanaman bawang sabrang ditanam mengelilingi pertanaman bawang merah.

Pertanaman tumpangsari lebih banyak diketahui mampu memberikan hasil tanaman secara keseluruhan yang lebih tinggi dibandingkan monokultur, apabila tepat dalam pemilihan spesies tanaman yang ditumpangsarikan (Permanasari dan Kastono, 2012). Pada penelitian ini terutama terkait dengan biaya benih umbi tanaman bawang sabrang.

\section{KESIMPULAN}

Efisiensi pemanfaatan lahan dan analisis finansial usaha tani terbaik terdapat pada perlakuan $120 \mathrm{~kg} \mathrm{ha}^{-1} \mathrm{~K}_{2} \mathrm{O}$ dengan pola tanam tanaman bawang sabrang mengelilingi pertanaman bawang merah yang berpenyakit moler.

\section{DAFTAR PUSTAKA}

Andersen, M. K. 2005. Competition and complementarity in annual intercrops the role of plant available nutrients. In Department of Soil Science,The Royal Veterinary and Agricultural University, Copenhagen. Denmark.

Handayani, A. 2011. Pengaruh model tumpang sari terhadap pertumbuhan dan hasil tanaman gandum dan tembakau. Jurnal Widyariset. 14(3): $479-488$.

Karima, S.S., M. Nawawi, \& N. Herlina. 2013. Pengaruh saat tanam jagung dalam tumpang sari tanaman jagung (Zea mays L.) dan brokoli (Brassica oleracea L . var. botrytis). Jurnal Produksi Tanaman. 1(3): 87 - 92.

Latarang, B., \& A. Syakur. 2006. Pertumbuhan dan hasil bawang merah (Allium ascalonicum L.) pada berbagai dosis pupuk kandang. Jurnal Agroland. 13(3): $265-269$.

Nugroho, B., D. Astriani, \& W. Mildaryani. 2011. Variasi virulensi isolat Fusarium oxysporum f.sp. cepae pada beberapa varietas bawang merah. Jurnal Agrin. 15(1): $8-17$.

Permanasari, I., \& D. Kastono. 2012. Pertumbuhan tumpangsari jagung dan kedelai pada perbedaan waktu tanam dan pemangkasan jagung. Jurnal Agroteknologi: 3(1): $13-20$. 
p-ISSN: 1410-0029; e-ISSN2549-6786

Agrin Vol. 23, No. 1, April 2019

Rifai, A., S. Basuki, \& B. Utomo. 2014. Nilai kesetaraan lahan budidaya tumpang sari tanaman tebu dengan kedelai: studi kasus di Desa Karangharjo, Kecamatan Sulang, Kabupaten Rembang. Jurnal Widyariset. 17(1): 59 - 70.

Sumarni, N., R. Rosliani, \& R. Basuki. 2012. Respons pertumbuhan, hasil umbi, dan serapan hara NPK tanaman bawang merah terhadap berbagai dosis pemupukan NPK pada tanah alluvial. Jurnal Hortikultura. 22(4): 366 - 375.

Timisela, N. R. 2008. Studi Kelayakan Industri Rumah Tangga Sago. Jurnal Agrin. 12(1): 42 - 55 . 